\title{
2008 European Football Championship - ECDC EPIDEMIC INTELLIGENCE SUPPORT
}

\author{
Peter Kreidl (peter.kreidl@ecdc.europa.eu)1 ${ }^{1}$, P Buxbaum²,3, F Santos- 0'Connor ${ }^{1}$, L Payne ${ }^{1}$, R Strauss ${ }^{4}$, H Hrabcik ${ }^{4}$, \\ H. C. Matter ${ }^{5}$, A Dreyfus 5 , P Arias ${ }^{1}$ \\ 1. European Centre for Disease Prevention and Control, Preparedness and Response Unit, Stockholm, Sweden \\ 2. The European Programme for Intervention Epidemiology Training (EPIET), Stockholm, Sweden \\ 3. Institut de veille sanitaire, Saint-Maurice, France \\ 4. Bundesministerium für Gesundheit, Familie und Jugend (Federal Ministry for Health, Family and Youth), Public Health \\ Directorate, Vienna, Austria \\ 5. Bundesamt fur Gesundheit (Federal Office of Public Health), Early Warning and Epidemiology Section, Bern, Switzerland
}

Mass gathering events may pose an increased risk for outbreak of infectious diseases, and a potential for rapid international spread $[1,2]$. Even events not considered relevant from the public health point of view can have a big media impact. The European Centre for Disease Prevention and Control (ECDC) has on several occasions given support to the European Union Member States (EU MS) during sporting events such as the Olympic Games and football championships to ensure the rapid detection of possible public health risks [3-6].

Between 7 and 29 June, the 2008 UEFA European Football Championship (Euro 2008) took place in eight towns of Austria and Switzerland. A total of 31 games were held, of which 16 took place in Austria. Football teams from twelve EU Member States, Switzerland, Russia and Turkey participated in the tournament. More than one million tickets were sold for match attendance and additional fans travelled to the organising countries to be present at the surrounding festivities. Besides the stadium venues, several fan zones and public viewing sites were set up in the organising countries and these were also taken into consideration in the public health preparedness activities $[7,8]$. The threat posed by the large ongoing outbreaks of measles in Austria and Switzerland were considered of particular relevance $[9,10]$.

The ECDC therefore collaborated with the Austrian and Swiss authorities providing both general support for the mass gathering event and specific support for the measles outbreak.

General support for the mass gathering

One month prior to the games, the ECDC and the Austrian health authorities co-organised a workshop to ensure coordination of preparedness activities in the organising countries and the EU institutions [11]. Participants of this meeting held at the Ministry of Health, Austria included national and regional health authorities, food safety and crisis management experts from both organising countries, and experts from the Robert Koch Institute, Berlin, Germany.

As agreed during the workshop, audio conferences between ECDC and the Ministries of Health of Austria and Switzerland were held on a daily basis, including weekends, for the entire period of the Euro 2008. In the daily audio conferences Austria and Switzerland provided updates on the epidemiological situation around the venue sites and ECDC informed about international health threats that could affect these countries and the Euro 2008 event. These threats were identified and assessed during the routine daily epidemic intelligence screening which takes place in ECDC on a $24 / 7$ basis.

During the event special editions of the ECDC Communicable Disease Threat Report (CDTR) and of the Austrian and Swiss national epidemiological bulletins, containing information on relevant health threats, were produced daily sent by email to dedicated Euro 2008 inboxes in ECDC and the Ministries of Health in Austria and Switzerland. In Austria the CDTR was further distributed to the Ministry of Interior, the food safety experts, the veterinary sector at national level and the regional authorities of the sites where the games were taking place. In Switzerland, it was forwarded to all involved sectors of the national health authorities and the national coordinated medical service of the Swiss army. Relevant information from the CDTR was imbedded in the national bulletins and sent to the regional authorities in both countries.

In addition, a senior expert from ECDC was seconded to Austria for the first week of the tournament and a fellow from the European Programme on Intervention Epidemiology Training (EPIET) was posted there for the entire period of the championship. Their tasks included support of the Austrian authorities in epidemic intelligence and outbreak verification activities. Furthermore, the ECDC agreed to provide assistance in outbreak investigation and response, if needed.

As Switzerland is not an EU Member State, as a rule the Swiss authorities do not have access to the EU Early Warning and Response System (EWRS). During the period of the Euro 2008, however, Switzerland was provided temporary access to information that could be relevant to the event.

Support for the measles outbreak

The initial risk assessment prepared by ECDC prior to the Euro 2008 identified that the measles outbreaks ongoing in both organising countries could have a potential for international spread. The outbreak in Switzerland began already in November 2006 
and 2,944 cases were reported until the start of the Euro 2008 (unpublished data) while the one in Austria started in March 2008 and 332 cases were reported before the event (unpublished data). A link between the two outbreaks had been confirmed both by genotyping and epidemiological investigation [10]. Both outbreaks involved cities where the tournament was taking place. In addition, measles cases were reported in the neighbouring countries of Italy and Germany [12, 13].

In April, experts from ECDC and EUVAC.NET visited Austria to assess the situation regarding the measles outbreak and participated in an expert consultation. Subsequently, information regarding the risk of measles transmission during the Euro 2008 was published in Eurosurveillance [14] and a mission report prepared (in press). Furthermore, ECDC encouraged all EU Member States to consider publishing recommendations on immunisation against measles for those planning to attend the championship [15]. This information was also published on ECDC website and distributed through EWRS, and the majority of EU Member States have circulated it through official websites and media or informed travel clinics and health authorities.

To better monitor the measles situation, Italy, Germany, Austria and Switzerland provided ECDC with weekly updates on the number of measles cases two weeks prior and after the Euro 2008. Weekly updating of ECDC about the measles situation from Austria and Switzerland is still ongoing.

\section{Reported public health events}

Apart from very localised and limited food borne-outbreaks, no infectious disease threats related to the Euro 2008 were identified during the entire period of enhanced epidemic intelligence, neither at national nor at international level.

Of special interest was an outbreak of Salmonella typhimurium reported by an EU Member State not participating in the tournament. This information was discussed during the daily audio conference, which alerted the Swiss authorities that subsequently identified a Salmonella typhimurium outbreak affecting most of their cantons. The outbreak was neither related to the originally reported event nor to the Euro 2008 but is an example of enhanced detection of public health threats.

Although transmission of measles was reported to occur at a low level during the Euro 2008, no single case was reported to be associated with the event. In the follow-up period one measles case was detected in Austria. Overall, the number of measles cases was decreasing in both countries.

\section{Conclusions}

All the participants agree that the daily exchange of information, the coordination epidemic intelligence and response activities at EU level and the close collaboration of the organising countries with ECDC has strengthened the established network of experts from different sectors nationally and internationally, which will function beyond the Euro 2008.

The secondment of experts enhanced the close collaboration between Austria and the ECDC, helped the Austrian authorities in managing the increased work load and provided a good experience of field work for the EPIET fellow.
The workshop was considered essential to provide dedicated time for exchange of experience and to harmonise preparedness activities planned by both organising countries. In addition, Austria and Switzerland considered the technical experience from ECDC and the Robert Koch Institute, which organised the FIFA football world in 2006 as very useful.

\section{Acknowledgement}

The authors would like to thank all participating stakeholders at local, regional and international level for their enthusiasm, excellent collaboration and transparency in sharing information. In addition, we would like to thank the Italian and Bavarian authorities for having shared data on measles on a weekly basis. Furthermore, they would like to thank the Commission and the Member States for agreeing that Switzerland had access to the EWRS information relevant for the championship for the period of the Euro 2008.

\section{References}

1. Kaiser R, Coulombier D. Epidemic intelligence during mass gatherings. Euro Surveill. 2006;11(51):pij=3100. Available from: http://www.eurosurveillance. org/ViewArticle. aspx?ArticleId $=3100$

2. World Health Organization. Communicable disease alert and response for mass gatherings. Available from: http://www.who.int/csr/mass_gathering/en/

3. Schenkel K, Williams C, Eckmanns T, Poggensee G, Benzler J, Josephsen J, Krause G. Enhanced Surveillance of Infectious Diseases: the 2006 FIFA World Cup experience, Germany. Euro Surveill. 2006;11(12):pii=670. Available from: http://www.eurosurveillance.org/ViewArticle.aspx?ArticleId=670

4. Franke F, Coulon L, Renaudat C, Euillot B, Kessalis N, Malfait P. Epidemiologic surveillance system implemented in the Hautes-Alpes District, France, during the Winter Olympic Games, Torino 2006. Euro Surveill. 2006;11(12):pii=671. Available from: http://www.eurosurveillance.org/ViewArticle. aspx?ArticleId $=671$

5. Editorial team. Health risks during the Cricket World Cup in the Caribbean: surveillance and assessment in the French départements. Euro Surveill. 2007;12(10):pii=3151. Available from: http://www.eurosurveillance.org/ ViewArticle.aspx?ArticleId=3151

6. Josephsen J, Schenkel K, Benzler J, Krause G. Preparations for infectious disease surveillance during the football World Cup tournament, Germany 2006. Euro Surveill. 2006;11(17):pii=2949. Available from: http://www. eurosurveillance.org/ViewArticle.aspx?ArticleId=2949

7. Strauss R, Muchl R, Hain C, Hrabcik H. EURO 2008 - preparations for the football championship in Austria. Euro Surveill. 2008;13(14):pii=8086. Available from: http://www.eurosurveillance.org/ViewArticle.aspx?ArticleId=8086

8. Dreyfus A, Marfurt J, Birrer A, Matter HC, Raeber P. Preparations for the European football championship (EURO 2008) in Switzerland. Euro Surveill. 2008;13(22):pij=18892. Available from: http://www.eurosurveillance.org/ ViewArticle.aspx?ArticleId $=18892$

9. Richard JL, Masserey-Spicher V, Santibanez S, Mankertz A. Measles outbreak in Switzerland - an update relevant for the European football championship (EURO 2008). Euro Surveill. 2008;13(8):pij=8043. Available from: http://www. eurosurveillance.org/ViewArticle.aspx?ArticleId $=8043$

10. Schmid D, Holzmann H, Abele S, Kasper S, König S, Meusburger S, et al. An ongoing multi-state outbreak of measles linked to non-immune anthroposophic communities in Austria, Germany, and Norway, March-April 2008. Euro Surveill. 2008;13(16):pii=18838. Available from: http://www.eurosurveillance.org/ ViewArticle.aspx?ArticleId $=18838$

11. Strauss R, Muchl R, Hain C, Kreidl P, Schenkel K, Thinus G, et al. Workshop EURO 2008: Zusammenarbeit des BMGFJ mit ECDC, der Europäischen Kommission und dem RKI. Available from: http://www.bmgfj.gv.at/cms/site/attachments/6/0/0/ CH0954/CMS1214142772770/workshop_euro_2008_(2)_(pk).pdf

12. Filia A, De Crescenzo M, Seyler T, Bella A, Ciofi Degli Atti ML, Nicoletti L, et al. Measles resurges in Italy: preliminary data from September 2007 to May 2008. Euro Surveill. 2008;13(29):pij=18928. Available from: http://www. eurosurveillance.org/ViewArticle. aspx?ArticleId=1892

13. Pfaff G, Mezger B, Santibanez S, Hoffmann U, Maassen S, Wagner U, et al. Measles in south-west Germany imported from Switzerland - a preliminary outbreak description. Euro Surveill. 2008;13(8):pii=8044. Available from: http:// www.eurosurveillance.org/ViewArticle.aspx?ArticleId $=8044$ 
14. Strauss R, Kreidl P, Muscat M, Coulombier D, Mulders M, Gijsens A, et al. The measles situation in Austria: a rapid risk assessment by an ECDC team and the outcome of an international meeting in Vienna, Austria. Euro Surveill. 2008;13(17):pii=18852. Available from: http://www.eurosurveillance.org/ ViewArticle.aspx?ArticleId $=18852$

15. European Centre of Disease Prevention and Control. ECDC information on measles vaccination. Available from: http://www.ecdc.europa.eu/Health_topics/ Measles/080423_travel_advice.html

This article was published on 7 August 2008.

Citation style for this article: Kreidl P, Buxbaum P, Santos-O'Connor F, Payne L, Strauss R, Hrabcik H, Matter HC, Dreyfus A, Arias P. 2008 European Football Championship - ECDC epidemic intelligence support. Euro Surveill. 2008;13(32):pii=18946. Available online: http://www.eurosurveillance.org/ViewArticle.aspx?ArticleId=18946 